\title{
Impact of Corporate Governance on Credit Rating
}

\author{
Christi Karolina Tarigan ${ }^{1}$, Fitriany Fitriany ${ }^{1 *}$ \\ ${ }^{1}$ Faculty of Economics and Business, Universitas Indonesia, Depok 16424, Indonesia \\ ${ }^{*}$ Corresponding Author: fitrianyamarullah@gmail.com
}

\begin{abstract}
This study aims to examine whether corporate governance affects a firm's credit rating. Corporate governance is examined from the aspects of company structure (number of directors, number of commissioners, and proportion of independent commissioners), ownership structure (institutional ownership, number of blockholders), audit committee, and external auditor. Using a sample of 168 firms listed in the Indonesia Stock Exchange (IDX) during the period 2009-2013, this study found that increasing board size, institutional ownership, audit committee and external auditor size have positive effects on a firm's credit rating, while increasing the proportion of outside directors and the size of blockholders has a negative effect. This research found that the number of directors has a quadratic inverse "U"-shape relation with credit ratings, with the maximum point at 4,589. To a certain extent, the greater the number of directors, the higher the credit rating, because the monitoring and decision making will be more effective. However, when the optimum point (five people) is reached, additional directors will decrease the credit rating due to coordination problems.
\end{abstract}

Keywords: Credit Rating; Board; Institutional Ownership; Blockholders; Audit Committee; External Auditor.

\section{INTRODUCTION}

Several previous studies have found a link between corporate governance and credit ratings. A study ${ }^{1}$ found that, among firms in the United States, effective oversight (indicated by percentage of institutional ownership) and independent outside directors have a positive impact on credit ratings and a negative impact on bond yields. As supervision becomes more effective, the possibility of default risk will decrease and credit rating will increase.

Another study ${ }^{2}$ also found that greater levels of institutional and managerial ownership will boost credit ratings due to the effective monitoring provided by institutional investors and management. Meanwhile, another study ${ }^{3}$ found that increasing board size, number of audit committees, and audit committee independence has a negative impact on the cost of debt. A lower cost of debt indicates a lower default risk, so credit ratings will increase.

Aman and Nguyen ${ }^{4}$ studied companies in Japan and found that corporate governance, which was measured based on the institutional ownership and transparency level, is positively associated with credit ratings. This effect occurs because institutional investors have effective oversight of management performance.

Research about the impact of corporate governance on credit ratings in Indonesia has been conducted by Setyaningrum ${ }^{5}$, who found that the number of blockholders and the level of institutional ownership are positively correlated with credit ratings, while insider ownership does not affect a firm's credit rating. The level of transparency and disclosure of financial information is also positively associated with a company's credit rating, while the board structure has no effect on credit ratings.

This study aims to examine the impact of corporate governance on a firm's credit rating. Corporate governance is analyzed from the aspects of company structure (number of directors, number of commissioners, and proportion of independent commissioners), ownership structure (institutional ownership, number of blockholders), audit committee, and external auditor.

The differences between this study and that of Setyaningrum ${ }^{5}$ are: 1) the range of the sample is increased to five years; 2) the variable of number of directors is added; 3 ) tests are carried out to determine whether the influence of the number of directors on credit rating is quadratic, and whether there is an optimal number of directors; and 4) public accounting firms are divided into three groups (Big 4, Second Tier, and Small). This study also differs from that of Aman and Nguyen ${ }^{4}$, as the variables of blockholders, audit committee, and external auditor are added. In addition, this study examines the quadratic relationship between the number of directors and the credit rating, while Aman and Nguyen ${ }^{4}$ only examined the linear relationship.

\section{LITERATURE REVIEW AND HYPOTHESIS DEVELOPMENT}

Prior studies ${ }^{6,7}$ found that increasing the numbers of boards would boost the market value. In addition, a large number of boards will be more profitable due to the tendency of the board to make decisions carefully, resulting in 
the occurrence of fewer mistakes in decision making ${ }^{4}$.

In contrast, other studies ${ }^{8,9}$ found that a large number of boards can cause coordination problems. This argument is supported by Yermack ${ }^{10}$ who found that firms in the United States with a large number of boards had lower market value due to coordination problems that would make decision making difficult. Cheng ${ }^{11}$ also found that the performance of a company with more boards is less stable because such companies tend to choose low-risk investments.

Based on the above findings, this study predicts that the number of directors will influence the credit ratings quadratically (concave). At first, increasing the number of directors will have a positive impact on the company, as it is run and overseen by more and more people. However, after a certain point, an increasing number of directors will create coordination issues that will cause difficulties in making decisions, thereby negatively affecting the company's credit rating.

In a two-tier state system, a company consists of a board of commissioners and a board of directors. This study focuses only on the board of directors because directors play an important role in the company that will affect the credit rating. Therefore, the hypothesis for this variable is:

H1: The number of directors has a quadratic effect on the credit rating.

The number of commissioners is an important aspect of corporate governance. A study ${ }^{12}$ state that the presence of a commissioner may represent the interests of all stakeholders. Monitoring by the commissioner may reduce agency risk and thereby improve the credit rating. The hypothesis for this variable is:

H2: Increasing the number of commissioners has a positive effect on the credit rating.

Bapepam-LK issued Rule Number IX.I.5 regarding the general provisions of independent commissioners. This regulation states that independent commissioners are members of the board of commissioners who have no affiliation with the company; in other words, they come from outside the company and do not own any shares either directly or indirectly in the company. Independent commissioners also have no relationship with other parties that may affect their ability to act independently. Bapepam-LK regulations state that the number of independent commissioners of a company should constitute at least $30 \%$ of the total board of commissioners.

In an effort to carry out his/her responsibilities properly, an independent commissioner must proactively encourage the board of commissioners to supervise and advise the board of directors. Independent commissioners are responsible for ensuring transparency and the disclosure of financial statements, the fair treatment of minority shareholders and other stakeholders, the disclosure of transactions that measure conflicts of interest fairly, guaranteeing corporate compliance with prevailing laws and regulations, and ensuring the accountability of corporate organs.

The proportion of independent commissioners is a very important component for directors and commissioners in the company. Independent boards are believed to be more effective in monitoring because they tend to have more objective opinions ${ }^{13}$. Aman and Nguyen ${ }^{4}$ state that an independent board has an important role in protecting the interests of creditors. This is consistent with prior research ${ }^{1}$, which found that firms with greater proportions of independent commissioners will have better corporate governance, resulting in reduced agency risk, improved credit ratings, and lower yields.

Based on previous studies, this study will investigate the effect the proportion of independent commissioners on the board has on credit ratings. Independent commissioners are expected to have a positive influence on credit ratings because their presence can lead to more effective oversight of management performance and more objective opinions, which will lower the agency risk and improve the credit rating of the company. The hypothesis for this variable is:

H3: Increasing the proportion of independent commissioners has a positive effect on the credit rating.

In this study, institutional ownership is measured based on the shares owned by investors from the financial sector, such as from banks, security companies, insurers, and financial institutions ${ }^{4}$. The presence of institutional investors as shareholders also tends to result in more effective monitoring. Effective monitoring will reduce agency problems because it can control opportunistic behavior by managers, thereby lowering the company's agency risk and causing the credit rating to increase. Shleifer and Vishny ${ }^{14}$ argue that institutional investors have an incentive to play an active role in monitoring company performance because they receive more benefits. One such benefit is voting power, which enables institutional investors to monitor and improve management decisions that do not fit the interests of investors. In addition, institutional investors have better industry knowledge than small investors and are therefore more effective in monitoring management performance ${ }^{15}$.

Institutional investors have several advantages over individual investors. Firstly, institutional investors have access to much more information than individual investors ${ }^{16}$. Secondly, institutional investors have a better ability to oversee management actions than individual investors ${ }^{17}$; institutional investors act as watchdogs through their investments.

Bhojraj and Sengupta ${ }^{1}$ argue that institutional ownership has a positive effect on credit ratings. This is because institutional investors have greater controlling power than individual investors, and supervisory activities can 
reduce agency risk. Furthermore, a study ${ }^{2}$ demonstrated that institutional ownership is associated with lower bond yields because effective monitoring by institutional investors reduces agency risk and thereby improves credit ratings. The same was found by Aman and Nguyen ${ }^{4}$, who determined that increasing the percentage of shares owned by institutional investors has a positive influence on the credit rating of a company. This is due to an effective supervisory mechanism employed by institutional investors that reduces a firm's agency risk.

Based on these studies, institutional ownership is predicted to have a positive effect on credit ratings because the presence of an institutional investor will improve the control mechanism of management actions, thereby reducing agency risk. If agency risk can be reduced, then the company will obtain a high credit rating. Therefore, the fourth hypothesis of this study is:

H4: Increasing institutional ownership has a positive effect on the credit rating.

The ownership structure is an important element in corporate governance, especially if, within the enterprise, there is institutional ownership or there are many blockholders ${ }^{5}$. Blockholders are investors with significant shareholdings in the company ${ }^{2}$. For the purposes of this study, blockholders are defined as shareholders owning $5 \%$ or more of the outstanding shares of the company, following the method used in the research conducted by Ashbaugh-Skaife ${ }^{2}$.

Studies carried out by Shleifer and Vishny ${ }^{18}$ and Jensen ${ }^{9}$ found that blockholders have a positive relationship with credit ratings. This happens because blockholders, who have a good investment in the form of debt or shares in a company, will be very concerned about whether corporate governance is functioning properly. Blockholders also have an interest in and a right to know about the policies and performance of management; they also have the power to pressure management if they perform deviant actions. This supervision undertaken by blockholders can reduce the agency problem. Similarly, Bhojraj and Sengupta's research ${ }^{1}$ found that credit ratings were positively associated with blockholders. This is a result of blockholders improving the level of supervision over the performance of the company such that management actions that are not in accordance with the interests of investors can be prevented.

In contrast, Ashbaugh-Skaife ${ }^{12}$ and Setyaningrum ${ }^{5}$ found that credit ratings were negatively associated with blockholders. This effect occurs because the presence of blockholders can force management to act and make decisions in accordance with their wishes; this causes the default risk to increase, which in turn leads to a decrease in the credit rating.

Based on the above argument, this research predicts that increasing the number of blockholders could have either a positive or negative impact on the credit rating. The existence of blockholders will improve the supervision so that management actions that are not in accordance with the interests of investors can be prevented. This will reduce the agency risk and lead to higher credit ratings. However, on the other hand, the presence of blockholders actually increases the ability of blockholders in pressuring management to take decisions that benefit them. This will result in increasing the default risk and lowering the credit ratings of the company. Therefore, the hypothesis is:

H5: The number of blockholders has positive and negative effects on the credit rating.

Bapepam-LK states that public companies are required to establish audit committees in accordance with applicable regulations. An audit committee is a committee established by and responsible to the board of commissioners in order to assist in carrying out the duties and functions of the board. The audit committee acts independently in fulfilling these duties and responsibilities. An audit committee should consist of at least three members, of which at least one must have an educational background and expertise in accounting or finance. One independent commissioner who is a member of the Audit Committee must act as Chairman of the Audit Committee ${ }^{19}$.

The audit committee is tasked with overseeing the company's financial reporting process and conducting regular meetings with external and internal auditors to provide professional opinions on the company's financial statements, audit processes and internal controls. The audit committee is also responsible for reviewing the financial information that will be issued by the company, such as financial reports and projections; the company's compliance with other laws and regulations relating to its activities; the execution of audits by internal auditors and the implementation of follow-up actions by the board of directors on the findings of internal auditors; and the implementation of risk management activities conducted by the board of directors. Moreover, the audit committee must advise the board of commissioners regarding any potential conflicts of interest, and maintain the confidentiality of documents, data, and company information.

Ashbaugh-Skaife ${ }^{2}$ attests to the presence of audit committees improving the quality and integrity of the audit process so that the financial information presented is more accurate. Ensuring the accuracy of the financial statements will lower the agency and default risks, thereby causing the credit rating to increase. The same effect was discovered by Setyaningrum ${ }^{5}$ in which the existence of an audit committee at a company would encourage it to publish more accurate financial statements, thereby lowering the agency and default risks, as well as improving the company's credit rating. Therefore, this study predicts that the existence of an audit committee that is in accordance 
with the rules set by Bapepam-LK will positively affect the credit rating of a company because its presence will improve the accuracy of the financial statements, thereby decreasing the default risk, which will lead to an increase in the credit rating of the company. As such, the hypothesis for this variable is as follows:

H6: A qualified audit committee has a positive effect on the credit rating of a company.

Sengupta ${ }^{20}$ stated that audit quality reflects the reliability and transparency of corporate financial information. Setyaningrum $^{5}$ found that firms audited by Big 4 firms have higher credit ratings than non-Big 4 audited firms. This effect occurs because the Big 4 acts as an independent party and therefore produces better audit quality. As such, they are able to reduce the creditors' doubts regarding the quality of financial statements, ultimately lowering the default risk and thereby increasing the credit ratings. In this research, public accounting firms are separated into three groups, namely, Big 4, Second Tier, and Small. Companies audited by Big 4 firms are expected to provide higher audit quality than those audited by Small firms. Moreover, Second Tier firms are predicted to provide higher audit quality than Small accounting firms. The hypotheses are:

H7: Companies audited by Big 4 and Second Tier firms have higher credit ratings than companies audited by Small accounting firms.

\section{RESEARCH METHOD}

The research model is as follows:

RATE $=\alpha_{0}+\alpha_{1}$ DIRSIZE $_{\mathrm{it}-1}+\alpha_{2}$ DIRSIZE $_{\mathrm{it}-1}^{2}+\alpha_{3} \mathrm{KMRS}_{\mathrm{it}-1}+\alpha_{4} \mathrm{KMRS}_{-} \mathrm{IND}_{\mathrm{it}-1}+\alpha_{5} \%_{\mathrm{INST}_{\mathrm{it}-1}}+\alpha_{6} \mathrm{BLOCK}_{\mathrm{it}-1}+$ $a_{7}$ KMTE_AUD $_{\text {it }-1}+a_{8}$ BIG4 $_{i t-1}+a_{9}$ SECOND_TIER $_{\text {it }-1}+a_{10}$ SIZE $_{i t-1}+a_{11}$ LEVG $_{\text {it }-1}+a_{12}$ ROA $_{\text {it }-1}+$ $a_{13}$ VLTLTS $_{\text {it }-1}+\varepsilon_{\text {it }} \ldots . . .(1)$

Where RATE: Credit rating, divided into seven groups following Ashbaugh-Skaife ${ }^{2}$, where 1 is the lowest rating and 7 is the highest rating (from PT Pefindo); DIRSIZE: Number of directors; KMRS: Number of commissioners who serve the company; KMRS_IND: Percentage of board of commissioners that are independent commissioners; \%INST: Percentage of shares owned by institutional investors, such as banks, security companies, insurers, and financial institutions; BLOCK: Number of shareholders owning 5\% or more of the outstanding shares; KMTE_AUD: If the audit committee is compliant with regulations, it is assigned a rating of 1; if not, it is assigned the value of 0; BIG4 and SECOND $\neg$ TIER: Dummy variable, d, is split into three groups (Big 4, Second Tier, and Small), which small auditor will be the basis.

\section{RESULTS AND DISCUSSIONS}

In this study, 242 data samples of outstanding bond from 2009-2013 (excluding financial industry) were obtained; 68 were from companies that were not listed, meaning only 174 data samples of bond from listed companies remained. There were six cases of incomplete data, resulting in a final sample size of 167. Table 1 shows descriptive statistics for the data.

Table.1. Descriptive Statistics

\begin{tabular}{lcrrrr}
\hline \multicolumn{1}{c}{ Variable } & N & \multicolumn{1}{c}{ Mean } & \multicolumn{1}{c}{ Min } & Max & Std. Dev. \\
\hline RATING & 168 & 5.244 & 1 & 7 & 1.209 \\
DIR_SIZE & 168 & 5.664 & 2 & 11 & 1.659 \\
DIR_SIZESQ & 168 & 34.660 & 4 & 121 & 21.077 \\
KMRS & 168 & 5.030 & 2 & 10 & 1.714 \\
KMRS_IND & 168 & 0.401 & 0.2 & 0.667 & 0.109 \\
KMTE_AUD & 168 & 0.809 & 0 & 1 & 0.410 \\
INST & 168 & 9.155 & 0 & 90.93 & 13.757 \\
BLOCK & 168 & 1.857 & 0 & 6 & 1.058 \\
BIG4 & 168 & 0.470 & 0 & 1 & 0.500 \\
SECOND_TIER & 168 & 0.423 & 0 & 1 & 0.496 \\
LNTA & 168 & 23.235 & 14.731 & 30.373 & 2.701 \\
LEV & 168 & 47.785 & 3.04 & 217.63 & 26.345 \\
ROA & 168 & 0.432 & -0.695 & 56.772 & 4.350 \\
VLTLTS & 168 & 37.890 & 14.210 & 71.193 & 8.113 \\
\hline
\end{tabular}

Table 2 shows that the variable DIR_SIZE has a significant positive correlation with credit rating, while DIR_SIZE2 has a significant negative correlation. Thus hypothesis 1 is proved as the number of directors has an inverted quadratic "U"-shape influence on credit ratings. To a certain extent, the higher the number of directors, the higher the credit rating, because the monitoring and decision making will be more effective (as indicated by the positive coefficient for the number of directors). However, when the optimum point is reached, additional directors will cause a deterioration in management performance (as indicated by the negative quadratic directional coefficients) because coordination problems will occur. A large number of directors will cause management 
performance to be unstable and will tend to invest at relatively low risk.

Mathematically, using the formula $-\mathrm{b} / 2 \mathrm{a}$ from the regression equation result, this study found that the optimal number of directors required to achieve the maximum credit rating of 6.983 is 4.589 (i.e., four or five people). These results show that increasing the number of directors up to four or five people could increase the credit rating of the company; however, exceeding that amount will lower the credit rating of the company.

KMRS (the number of commissioners) does not affect the credit rating. This finding is in accordance with Setyaningrum's study ${ }^{5}$, which states that increasing the number of commissioners does not always benefit the creditor, as greater and greater numbers of commissioners will complicate decision making. For this reason, the influence of the number of commissioners is insignificant.

Table.2. Regression Result

\begin{tabular}{|c|c|c|c|}
\hline RATING & Prediction & Coefficient & P-Value \\
\hline DIR_SIZE & + & 0.358 & $0.041 * *$ \\
\hline DIR_SIZESQ & - & -0.039 & $0.009 * * *$ \\
\hline KMRS & + & 0.031 & 0.218 \\
\hline KMRS_IND & + & -1.090 & $0.042 * *$ \\
\hline KMTE_AUD & + & 0.264 & $0.055^{*}$ \\
\hline$\%$ INST & + & 0.008 & $0.047 * *$ \\
\hline BLOCK & $+/-$ & -0.228 & $0.000 * * *$ \\
\hline BIG4 & + & 0.819 & $0.000 * * *$ \\
\hline SECOND_TIER & + & 0.480 & $0.013 * *$ \\
\hline LNTA & + & 0.047 & $0.017 * *$ \\
\hline LEVG & - & -0.025 & $0.000 * * *$ \\
\hline ROA & + & 0.042 & 0.247 \\
\hline VLTLS & - & -0.066 & $0.000 * * *$ \\
\hline CONST & & 6.160 & 0.041 \\
\hline Adjusted $\mathrm{R}^{2}$ & $57.56 \%$ & & \\
\hline F Stat & 0.000 & $\mathrm{~N}$ & 168 \\
\hline
\end{tabular}

The increasing the number of independent commissioners has a negative effect on the credit rating. These findings contradict the research hypothesis. However, Setyaningrum ${ }^{5}$ also did not find the impact of independent commissioners on credit ratings in Indonesia to be significant.

Institutional ownership has significant positive effects on the credit rating of a company. The greater the institutional ownership, the higher the company's corporate credit rating. These findings support the research of Aman and Nguyen ${ }^{4}$, Ashbaugh-Skaife ${ }^{2}$, and Setyaningrum ${ }^{5}$ in which it was found that institutional investors will improve the oversight of the company's management performance so that creditors and other stakeholders will not be harmed. Supervision of the performance of management by institutional investors also makes the lender feel protected from any possible risk of default on the part of the company.

BLOCK (the number of shareholders holding $5 \%$ or more of the outstanding shares) negatively affects the credit rating. This is because the greater the number of blockholders, the greater the percentage of shares owned by blockholders. This will increase the blockholders' ability to pressure management to make decisions that benefit them, for example, to make investments that will result in high returns. If the investment is successful, then the company will benefit from rising stock prices; however, if the investment fails, then the creditor will suffer losses because the company neglected to pay its obligations. This will cause the credit rating to fall. The results of this variable test support research conducted by Ashbaugh-Skaife ${ }^{2}$ and Setyaningrum ${ }^{5}$, in which it was demonstrated that increasing the number of blockholders will make the credit rating lower.

KMTE AUD (audit committee) has a significantly positive effect on the credit rating of a company. The results indicate that firms that have audit committees which are in accordance with regulations have higher credit ratings. This is because the presence of such audit committees will reduce agency risk, and will thereby improve the credit rating.

Firms audited by Big 4 auditors have higher credit ratings than firms audited by Small auditors. Meanwhile, firms audited by Second Tier auditors have higher credit ratings than those audited by Small auditors. Firms audited by Big 4 auditors have the highest credit ratings because they act as an independent assurance party, which could reduce creditors' doubts about the quality of financial statements, ultimately reducing the default risk and increasing the credit rating of the company.

The control variable size shows that size has a significant positive effect on credit rating. The bigger a company, the higher its credit rating. Larger companies can obtain loans from creditors more easily because they are considered able to survive and compete in the industry, so their risk of defaulting is low. These results are similar to those of the prior studies ${ }^{1,2,4}$. 


\section{CONCLUSION}

This research found that the number of directors on the board has a significant quadratic impact on credit rating. The optimal number of directors is five people. The number of commissioners has no effect on the credit rating of a company. This is may be because the greater the number of commissioners, the more complicated the decisionmaking process. Increasing the proportion of independent commissioners negatively affects the credit rating of a company. A reason for this finding may be that the independent commissioner does not perform his/her duties and responsibilities effectively. Institutional ownership has a significant positive effect on the company's credit rating, because the institutional investors can raise the company's credit rating.

The number of blockholders significantly affected the credit rating of the company. The greater the number of blockholders in the company, the lower the credit rating; this effect occurs because their presence can encourage management to make decisions in accordance with the interests of blockholders.

Audit committees proved to have a positive influence on credit ratings. Companies that have audit committees which are in accordance with Bapepam-LK regulations have a higher credit rating than those whose audit committees are noncompliant with Bapepam-LK regulations.

Both the Big 4 and Second Tier auditors were shown to have positive and significant effects. It was concluded that companies audited by Big 4 firms have higher credit ratings than those audited by Second Tier and Small firms. Likewise, companies audited by a Second Tier firm have higher credit ratings than those audited by a Small firm.

A limitation of this research is that the measurement of blockholders does not consider ultimate ownership; it is recommended that future research employ ultimate ownership in its measurement.

\section{REFERENCES}

[1] S Bhojraj, P Sengupta. Effect of corporate governance on bond ratings and yields: The role of institutional investors and outside directors. Journal of Business, 76 (2003) 455-475.

[2] H Ashbaugh-Skaife, D Collins, R LaFond. The effects of corporate governance on firm's credit ratings. Journal of Accounting and Economics, 42(1-2) (2006) 203-243.

[3] R Anderson, S Mansi, D Reeb. Board characteristics, accounting report integrity, and the cost of debt. Journal of Accounting and Economics, 37(3) (2004) 315-342.

[4] H Aman, P Nguyen. Does good governance matter to debtholders? Evidence from the credit rating of Japanese firms. Research in International Business and Finance, 29(2) (2013) 14-34.

[5] D Setyaningrum. Pengaruh mekanisme corporate governance terhadap peringkat surat utang perusahaan di Indonesia. Jurnal Akuntansi dan Keuangan Indonesia, 2(2) (2005) 73-102.

[6] CG Raheja. Determinants of board size and composition: A theory of corporate boards. Journal of Financial and Quantitative Analysis, 40(2) (2005) 283-306.

[7] M Harris, A Raviv. A theory of board control and size. Review of Financial Studies, 21(4) (2008) 1797-1832.

[8] M Lipton, JW Lorsch. A modest proposal for improved corporate governance. Business Lawyer, 48(1) (1992) 59-77.

[9] MC Jensen. The modern industrial revolution, exit, and the failure of internal control systems. Journal of Finance, 48 (1993) $831-880$.

[10] D Yermack. Higher market valuation of companies with a small board of directors. Journal of Financial Economics, 40(2) (1996) 185211.

[11] S Cheng. Board size and the variability of corporate performance. Journal of Financial Economics, 87 (2008) 157-176.

[12] H Ashbaugh-Skaife, D Collins, R LaFond. The Effects of Corporate Governance on Firms' Credit Ratings. Working Paper, University of Iowa (2004).

[13] BE Hermalin, MS Weisbach. Endogenously chosen boards of directors and their monitoring of the CEO. American Economic Review, 88(1) (1998) 96-118.

[14] A Shleifer, RW Vishny. Large shareholders and corporate control. Journal of Political Economy, 94(3) (1986) 461-488.

[15] J McConnell, H Servaes. Additional evidence on equity ownership and corporate value. Journal of Financial Economics, 27 (1990) 595 612.

[16] B Lev. Toward a theory of equitable and efficient accounting policy. The Accounting Review, 63 (1988) 1-22.

[17] A Rahmawati, H Triatmoko. Analisis Faktor-Faktor yang Mempengaruhi Kualitas Laba dan Nilai Perusahaan. Proceeding Simposium Nasional Akuntansi (SNA) X, Makassar (2007).

[18] A Shleifer, R Vishny. A survey of corporate governance. Journal of Finance, 52 (1997) 737-783.

[19] Badan Pengawas Pasar Modal dan Lembaga Keuangan (Bapepam-LK). Peraturan Nomor IX.I.5 - Keputusan Ketua Bapepam-LK Nomor KEP-643/BL/2012 tentang Pembentukan dan Pedoman Pelaksanaan Kerja Komite Audit. Badan Pengawas Pasar Modal dan Lembaga Keuangan (Bapepam-LK), Jakarta (2012).

[20] P Sengupta. Corporate disclosure quality and the cost of debt. The Accounting Review, 73(4) (1998) 459-474. 